UDC 378.22:159.947.3

DOI 10.35433/pedagogy.1(96).2019.26-32

N. M. Myronchuk,

Candidate of Pedagogical Sciences, Associate Professor,

(Zhytomyr Ivan Franko State University)

mironchuk_nm@i.ua

ORCID : $0000-0002-1360-6381$

O. O. Makarevych,

Lecturer of Department of Foreign Languages and the Modern Teaching Techniques

(Zhytomyr Ivan Franko State University) makarevoleg@ukr.net

ORCID : $0000-0002-0887-1359$

\title{
RESEARCH OF VOLITIONAL EFFORTS IN A STRUCTURE OF A REGULATORY-VOLITIONAL COMPONENT OF READINESS TO SELF- ORGANIZATION IN PROFESSIONAL ACTIVITY OF A FUTURE LECTURER IN HIGHER EDUCATION
}

The article substantiates the role of volitional efforts as an important and effective motive for master candidates' activity in improving their level of academic and professional experience, as well as their readiness for selforganization in professional pedagogical activities for the purpose of professional self-development and selfimprovement. It is noted that the volitional efforts of an individual carry out a regulatory and mobilizing effect within mental and physical self-organization of a future specialist in professional activities.

The diagnostic study of volitional efforts formation indicators of future lecturers in higher education is carried out on the basis of reflective introspection usage and self-assessment of the formation of appropriate abilities and properties. Also utilized were techniques developed by H. Levenson, a questionnaire for self-organization research by $O$. Mandrykova, and a self-certification questionnaire. According to the results of the diagnosis, there is a lack of formation of the following factors within future lecturers in higher education: self-control of actions, states, and emotions in situations of interaction; self-control of actions in stressful situations; fulfillment of educational / professional tasks on time; the ability to refuse to perform excessive tasks; and planning forms and methods of self-development and implementation of self-education. Organizational and pedagogical conditions of volitional skills development within future lecturers in higher education are stated as: creation of a corresponding reflexive and evaluative developmental environment by providing problem-oriented training content; organization of reflexivity and regulatory activity of master candidates in process of classroom and outof-school activities; acquaintance of master candidates with methods and techniques of self-regulation and selfcontrol; systematic self-examination and self-control by a master candidate of their own methods and techniques in educational work, self-evaluation and self-correction of their activities in a process of training and selftraining. The organizational and didactic possibilities of a discipline "Fundamentals of self-organization in professional activity" are presented in formation of skills of volitional self-regulation within master candidates.

Key words: self-organization, volitional efforts, regulatory-volitional component, future lecturers in higher education.

Introduction. A professionally demanded quality of a lecturer in higher education within the conditions of modern educational reforms is the ability of self-organization. This ability is recognized as an important factor, the means of which provide an effective solution for professional activity tasks, their self-fulfillment and self-development. The necessity of the formation of self-organization skills within pedagogical professionals in higher education is declared by state educational acts (Law of Ukraine "On Higher Education" (2014), the National Strategy of Education Development in Ukraine until 2021, the National Qualifications Framework (2011), the Concept of Teacher Education Development (2018)) in which a leading professional activity criterion for future lecturers in higher education institutions is stated as an ability to think freely and to possess the skills and abilities of selforganization within modern times. It is further stated that the ability to make decisions and 
deal with complex problems and tasks in professional activities under conditions of uncertainty and unpredictability is also of crucial importance.

Scholars consider self-organization as an important aspect of the student management of their own educational activities and means of its effective organization (J. Agolla, J. Borkowski, C. Wibrowski, M. Dembo, O. Demchenko, B. Zimmerman, N. Dudnik, J. Lloyd, H. Ongori, etc.).

Researchers $[4 ; 7 ; 8 ; 6]$ argue that students who possess self-organization skills can set goals themselves, effectively solve problems, maintain positive thinking within academic challenges, use resources effectively, structure their environment according to their own needs and goals, and are able to analyze causes of failures for needs of further selfdevelopment. Thus, scholars distinguish a number of components of self-organization: motivation, teaching methods, time management, physical and social environment, and productivity, which, as M. Dembo notes [4], should be a basis for their overall integration into the educational process.

The improvement of the self-organization skills of students in educational activities, according to researchers $[2 ; 4 ; 6 ; 8]$, is connected with development of their self-awareness, cognitive interests, internal motivation, and regulatory skills.

The theoretical foundation of volition as a mechanism of the self-regulation of human behavior is substantiated by I. Bech, L. Vygotsky, V. Selivanov, S. Rubinstein, etc. Diagnostic studies of the formation of the volitional qualities of students is made by M. Necheporenko and M. Chebotaryov. Pedagogical tasks related to the formation of volitional skills and the development of volition as a component of readiness of future specialists for professional activity are solved by M. Grinev, M. Necheporenko, V. Chudakova, etc. In particular, V. Chudakova [3: 39-47] considers "self-willed control" as one of the components of integrated emotional and volitional spheres of an individual within a structure of psychological readiness for innovation and competitiveness in rapidly changing circumstances. M. Necheporenko [5] substantiates a system of principles and methods of influence concerning the volitional-emotional component of a student in professional and educational training. The research combines the volitional culture of a student's personality with the ability to identify activity or passivity, readiness for decision-making or showing restraint.

Aim of the study. This study considers volitional efforts as an important motivating factor for a future lecturer in higher education activity to improve their academic and professional experience. This includes a readiness to self-organize in professional activities in order to better self-development and self-improvement. Therefore, the purpose of the article is to substantiate results of a study analyzing the level of formation of volitional efforts. These will be examined within the context of a structure of the volitional component readiness of future lecturers in higher education (specialty 011 "Educational, Pedagogical Sciences") for selforganization in professional activities, as well as outlining ways in which they are formed.

Methods. The research used the following methods: theoretical analysis in order to identify the essential features of volitional self-regulation as a component of selforganization; diagnostic study including questionnaires, standardized techniques, reflexive analysis, and self-esteem with an aim of identifying the level of manifestation of volitional qualities in future lecturers of higher education within the context of their self-organization within educational and professional activities.

Results. Self-organization of a higher education lecturer in professional pedagogical activity is a conscious activity, which is induced and aimed at goals and values of organization, self-management, self-improvement in professional activities, preservation of professional health, balance between personal and professional resources. Self-organization is carried out by a system of intellectual, motivational, volitional actions and is directed at 
solving problems of the rational organization of work and effective implementation of a teacher's volitional tasks.

The generally recognized structure of self-organization as a pedagogical concept is the interaction and interconnection of various components including goal-definition, analysis, planning/designing of actions, as well as designing/implementing of invariant of an action / solution through implementation of volitional efforts.

The notion of "volition" can be used in various aspects including as a manifestation of a desire to act, as conscious decision-making in a situation of a choice, and /or as perseverance and purposefulness. Volition is one of the mechanisms that allow managing behavior, mental processes and motivation.

According to I. Bech, the volition displays of a person are directed not at the outside world, but at the person themselves. Volitional regulation is characterized by deliberate intentionality of behavior, which is based on development of a plan. This plan may include a program for achieving a goal, a conscious choice of a certain mode of action from a number of possible ones, assessment of an obstacle to a goal, or the need to mobilize volitional efforts to overcome obstacles [1: 488]. Such functional characteristics of volition give reason to consider it not only as a part of a regulatory-volitional component, but also as a conscious, arbitrary action in the structure of value-motivational, content-cognitive, operational-active and reflexivity-valued components of the readiness of future higher education lectures to selforganization in professional activity.

The level of formation of volitional efforts in combination with other components of selforganization determines the strategy of a lecturer in professional activities. An implementation of self-processes such as self-examination, self-reflection, self-motivation, self-regulation, self-regulation, self-control, occurs through a volitional act, which results in the goal of self-organization. Volition performs regulatory and mobilization functions in the mental and physical self-organization of a future professional within his / her professional activity.

Studying various issues of self-organization in the professional activity among lecturers in higher educational institutions such as lack of time, lack of experience in organizing professional activities, and lack of planning skills, makes it possible to distinguish a factor associated with imperfection formation of a volitional component. In particular, $42 \%$ of lecturers and $37,5 \%$ of master candidates consider their passivity as one reasons for an inefficient organization of vocational / educational activities.

In order to identify the level of formation and degree of expression of the volitional efforts of future lecturers in higher education, the following diagnostic methods have been applied: reflexive self-analysis, master candidates' self-assessment of the formation of corresponding abilities and properties, techniques developed by H. Levenson in "The Scale of the Inner Essence, Strong World and Case", a self-organization activity questionnaire by O. Mandrykova, and a self-certification questionnaire "Formation of Ability to SelfOrganization in Educational / Professional Activity".

The research presents results of a survey taken by 77 teachers who work in different types of higher education institutions (university, institute, college) and 68 master candidates who qualify as teachers in higher education institutions located in the Zhytomyr, Rivne and Sumy regions.

The results of the self-assessment of master candidates and teachers regarding indicators of volitional efforts in the process of self-organization in educational/professional activities indicate that there are issues in various areas. These areas include the field of self-control of emotional states, adequate actions in stressful situations, planning of forms and methods of self-development and implementation of self-education. Respondents evaluate their ability to refuse a task / assignment and the ability to delegate tasks particularly low (Table 1). 
Table 1

Results of master candidates' self-evaluation of indicators of manifestation of volitional efforts in a process of self-organization in educational / professional activities

\begin{tabular}{|c|c|c|c|c|c|c|c|c|c|}
\hline \multirow[t]{3}{*}{ № } & \multirow{3}{*}{$\begin{array}{l}\text { Indicators of } \\
\text { manifestation of } \\
\text { volitional efforts }\end{array}$} & \multicolumn{8}{|c|}{ Levels of manifestation (\%) } \\
\hline & & \multicolumn{2}{|c|}{ low } & \multicolumn{2}{|c|}{ medium } & \multicolumn{2}{|c|}{ sufficient } & \multicolumn{2}{|c|}{ high } \\
\hline & & mas. & lec. & mas. & lect. & mas. & lect. & mas & lect. \\
\hline 1 & $\begin{array}{l}\text { Self-control of actions, } \\
\text { states, emotions in } \\
\text { situations of interaction }\end{array}$ & 8,8 & 2,6 & 27,9 & 24,7 & 36,8 & 48,0 & 26,6 & 24,7 \\
\hline 2 & $\begin{array}{l}\text { Self-control of actions in } \\
\text { stressful situations }\end{array}$ & 4,4 & 10,3 & 48,5 & 29,9 & 30,9 & 33,7 & 16,2 & 25,9 \\
\hline 3 & $\begin{array}{l}\text { Planning forms and } \\
\text { methods of self- } \\
\text { development }\end{array}$ & 8,8 & 5,2 & 30,9 & 25,9 & 45,6 & 46,8 & 14,7 & 22,1 \\
\hline 4 & Self-education activities & 7,4 & 6,5 & 23,5 & 22,0 & 52,9 & 40,3 & 16,2 & 31,2 \\
\hline 5 & $\begin{array}{l}\text { Fulfillment of tasks of } \\
\text { professional activity, } \\
\text { orders in time }\end{array}$ & 0,0 & 6,5 & 27,9 & 25,9 & 45,6 & 44,2 & 26,5 & 23,4 \\
\hline 6 & $\begin{array}{l}\text { Ability to refuse to } \\
\text { perform task / assignment } \\
\text { (delegate task) }\end{array}$ & 35,3 & 26,0 & 30,9 & 23,4 & 16,2 & 39,0 & 17,6 & 11,6 \\
\hline & Average indicator & 10,3 & 9,0 & 32,4 & 26,0 & 38,2 & 41,6 & 19,1 & 23,4 \\
\hline
\end{tabular}

H. Levenson's technique was used to identify the level of volitional effort that a master candidate shows in solving life problems. This technique states that a person either has faith in their own volitional powers, a disbelief in their own ability or a belief that a course of life events is determined by fortune. Hence, a high level of self-determination was recorded in $12,5 \%$ of respondents, sufficient in $31,3 \%$, and medium in $56,2 \%$.

Similar results were revealed with the help of a self-organizing questionnaire by O. Mandrykova on the scale of "perseverance". 4,4\% of graduate students have weak activity volition, as they can proceed to perform another action without completing the previous one. In 55,9 \% of respondents, a medium level of the manifestation of volitional efforts is reported. They are characterized by a tendency of easy distraction. 30,9\% of master candidates show sufficient self-organization, but they tend to leave an uninteresting task and switch to more significant activities. Only $8,8 \%$ of people are able to structure their behavioral activity and complete an initiated effort by the efforts of volition.

The generalized indexes of master candidates' degree of volitional effort, revealed by the results of the methodology and self-assessment of masters, are presented in Table 2.

Table 2

Indicators of formation of volitional qualities in postgraduate students based on results of techniques and self-esteem, $\%$

\begin{tabular}{|l|c|c|c|c|c|c|}
\hline \multirow{2}{*}{ Levels of formation } & \multicolumn{2}{|c|}{$\begin{array}{c}\text { By results of } \\
\text { techniques }\end{array}$} & \multicolumn{2}{c|}{$\begin{array}{c}\text { According to the results } \\
\text { of self-evaluation }\end{array}$} & \multicolumn{2}{c|}{ Average indicator } \\
\cline { 2 - 7 } & number & $\%$ & number & $\%$ & number & $\%$ \\
\hline High & 7 & 10,3 & 13 & 19,1 & 10 & 14,7 \\
\hline Sufficient & 21 & 30,9 & 26 & 38,2 & 23 & 33,8 \\
\hline Medium & 38 & 55,9 & 22 & 32,4 & 30 & 44,1 \\
\hline Low & 2 & 2,9 & 7 & 10,3 & 5 & 7,4 \\
\hline Total & 68 & 100 & 68 & 100 & 68 & 100 \\
\hline
\end{tabular}


It should be noted that an appropriate level of formation of volitional qualities reflects the ability of future lecturers in higher education to self-motivate, self-regulate, mobilize efforts, and manifest his / her own activity in solving professional tasks or overcoming contradictions. This fulfills a function of the preservation/restoration of mental forces in unexpected situations or in a case of monotonous activities or the impact of monotonous factors.

The following organizational-pedagogical conditions of the development of vocational skills are defined within the context of future higher education lecturers' self-organizing capabilities:

- creation of a corresponding reflexive-estimation developing environment by providing a problematic educational content;

- organization of reflexivity and regulatory activity in the process of classroom and out-ofschool activities;

- awareness of methods and techniques of self-direction and self-control;

- systematic self-examination and self-control of methods and techniques of educational work, self-evaluation and self-correction of activities in educational process and self-training.

Purposeful formation of the skills of volitional self-regulation as a component of the regulatory-volitional component of the readiness of future lecturers in higher education occurs in the process of studying the discipline "Fundamentals of self-organization in professional activity", which organizational-didactic capabilities are presented in Figure 1.

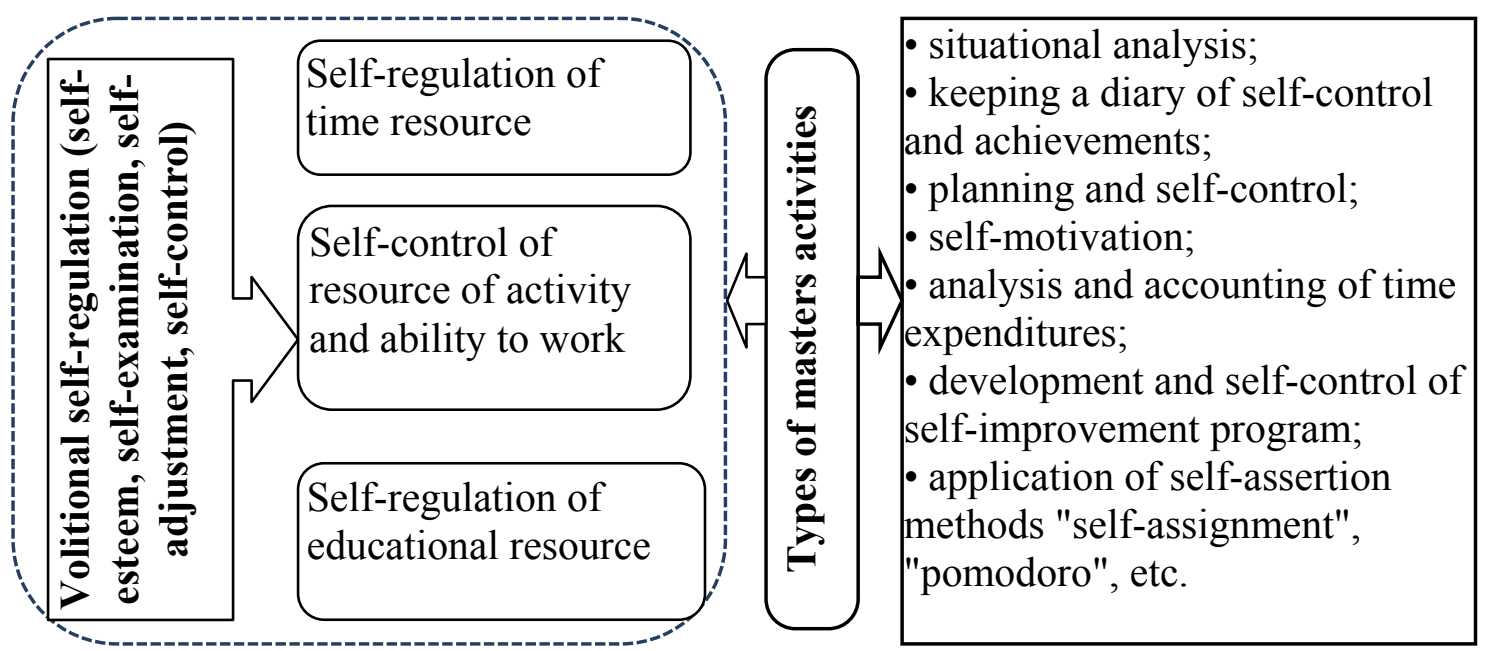

Fig. 1. Content and methods of development of skills of voluntary self-regulation in a process of studying a discipline "Fundamentals of self-organization in professional activity"

The content and extent of training tasks for volitional self-regulation and self-control skills covered in "Fundamentals of self-organization in vocational activity" include: 1) planning and self-monitoring of daily training activities (task setting, prioritization of cases, selfassignment, implementation of a reminder method for a task, recording and fixing time for an execution of tasks); 2) establishment of tactical and strategic goals of personal selfimprovement and control of their own progress; 3) self-motivation; 4) assessment of a degree of execution of a planned action (reception "approval", "rule of three minutes", "rule 21", etc.). The formation of volitional skills of master candidates took place in conjunction with the development of the motivational-value sphere, the content-cognitive component and reflexivity-assessment skills.

Conclusions. Volitional efforts are an important and effective impetus for master candidates to increasing their level of academic and professional experience, as well as their readiness to self-organize in vocational pedagogical activities for the purpose of professional self-development and self-improvement. The results of the diagnostic study showed an 
inadequate level of formation of indicators of this component in future lecturers in higher education. This was true in particular regarding the level of self-control of emotion formation, actions in stressful situations, an ability to carry out tasks on time, abandoning excessive tasks, planning forms and methods of self-development and implementation of self-education.

It is believed that the development of a corresponding reflexive-evaluative environment by introducing into teaching content appropriate methods of work is an important factor in constructive influence on processes of personal and professional development of a future lecturer in higher education and formation of their readiness for self-organization situations in professional activity. Methods of formation of this readiness are a prospect of further analysis.

\section{REFERENCES (TRANSLATED \& TRANSLITERATED)}

1. Bekh, I.D. (2008). Vykhovannia osobystosti [Character education]. Kyiv: Lybid [in Ukrainian].

2. Borkowski, J. G., \& Thorpe, P. K. (1994). Self-regulation and motivation: A life-span perspective on underachievement. Self-regulation of learning and performance: Issues and educational applications. Hillsdale, NJ: Lawrence Erlbaum Associates (pp. 45-73) [in English].

3. Chudakova, V. P. (2015). Doslidzhennia "voliovoho samokontroliu/voliovoi samorehulyatsii" pokaznyka sformovanosti psykholohichnoi hotovnosti do innovatsiinoi diial'nosti y konkurentozdatnosti osobystosti: diahnostychno-interpretatsiinyi komponent [The study of "volitional self-control / volitional self-regulation" - an indicator of formation of psychological readiness for innovation and competitiveness of an individual: a diagnostic-interpretative component]. Osvita i rozvytok obdarovanoi osobystost - Education and Development of Gifted Person, 1, 39-47 [in Ukrainian].

4. Dembo, M. H. (2004). Motivation and learning strategies for college success: A self-management approach. New Jersey: Lawrence Erlbaum Associates [in English].

5. Necheporenko, M. V. (2011). Emotsiino-voliova kultura studenta [Emotional-volitional culture of a student]. Kharkiv: KHNU imeni V.N. Karazina [in Ukrainian].

6. Pintrich, P. R., \& De Groot, E. V. (1990). Motivational and self-regulated learning components of classroom academic performance. Journal of Educational Psychology, 82, 33-40 [in English].

7. Zimmerman, B.J. (1994). Dimensions of academic self-regulation: A conceptual framework for education. Self-regulation of learning and performance: Issues and educational applications. Hillsdale, NJ: Lawrence Erlbaum Associates (pp. 3-21) [in English].

8. Zimmerman, B. J., \& Martinez-Pons, M. (1990). Student differences in self-regulated learning: Relating grade, sex, and giftedness to self-efficacy and strategy use. Journal of Educational Psychology, 82, 5159 [in English].

Received: January 16, 2018

Accepted: March 26, 2019

\section{Дослідження вольових зусиль у структурі регулятивно-вольового компонента готовності майбутнього викладача вищої иколи до самоорганізації у професійній діяльності.}

У статті обтрунтовано роль вольових зусиль як важливої дійової спонуки активності магістрантів у підвищенні ними рівня набутого академічного і професійного досвіду та їх готовності до самоорганізації у професійній педагогічній діяльності з метою професійного саморозвитку $i$ самовдосконалення. Зазначено, щзо вольові зусилля особистості виконують регулятивну та мобілізаційну дію в психіній та фізичній самоорганізації майбутнього фахівия у професійній діяльності.

Здійснено діагностичне вивчення показників сформованості вольових зусиль у майбутніх викладачів вищеӧ школи на основі використання рефлексивного самоаналізу, самооцінки сформованості відповідних умінь та властивостей; методики Х. Левенсона, опитувальника самоорганізації діяльності

О. Мандрикової; самосертифікаційного опитувальника. За результатами діагностики встановлено недостатній рівень сформованості у майбутніх викладачів вищої цколи таких показників:

самоконтроль дій, станів, емочій у ситуаціях взаємодї; самоконтроль дій у стресових ситуаціях; своєчасне виконання завдань навчальної / професійної діяльності; здатність відмовлятися від виконання надмірних завдань; планування форм та методів саморозвитку і здійснення самоосвіти. Названо організаційно-педагогічні умови розвитку вольових умінь у майбутніх викладачів вищої школи:

створення відповідного рефлексивно-оцінного розвивального середовища иляхом надання змісту підготовки проблемного характеру; організація рефлексивно-регулятивної діяльності магістрантів у процесі аудиторних та позааудиторних занять; ознайомлення магістрантів із методами та прийомами саморегуляиї й самоконтролю; систематичний самоаналіз та самоконтроль магістрантом методів $i$ 
прийомів власної навчальної прачі, самооцінка і самокорекція своєї діяльності у процесі навчання та самопідготовки. Представлено організаційно-дидактичні можливості навчальної дисиипліни "Основи самоорганізації у професійній діяльності" у формуванні в магістрантів умінь вольової саморегулямії.

Ключові слова: самоорганізачія, вольові зусилля, регулятивно-вольовий компонент, майбутній викладач вищчої иколи. 